\title{
The chemical forms of water-soluble microparticles preserved in the Antarctic ice sheet during Termination I
}

\author{
Toshimitsu SAKURAI, ${ }^{1,2}$ Hiroshi OHNO, ${ }^{1,3}$ Shinichiro HORIKAWA, ${ }^{1}$ \\ Yoshinori IIZUKA, ${ }^{1}$ Tsutomu UCHIDA, ${ }^{4}$ Kazuomi HIRAKAWA, ${ }^{5}$ Takeo $\mathrm{HONDOH}^{1}$ \\ ${ }^{1}$ Institute of Low Temperature Science, Hokkaido University, Sapporo 060-0819, Japan \\ E-mail: sakurai.toshimitsu@ilt.or.jp \\ ${ }^{2}$ Institute for Laser Technology, 2-6 Yamada-oka, Suita, Osaka 565-0871, Japan \\ ${ }^{3}$ Hokkaido National Industrial Research Institute, Sapporo 062-8517, Japan \\ ${ }^{4}$ Graduate School of Engineering, Hokkaido University, Sapporo 060-8628, Japan \\ ${ }^{5}$ Graduate School of Environmental Science, Hokkaido University, Sapporo 060-0810, Japan
}

\begin{abstract}
This study clarifies changes in the chemical forms of microparticles during Termination I, the period of drastic climate change between the Last Glacial Maximum (LGM) and the Holocene. We determine the chemical forms of individual water-soluble microparticles through micro-Raman spectroscopy and compare the relative frequencies of different types with the ion concentrations in melted ice. Micro-Raman spectroscopy shows that $\mathrm{Na}_{2} \mathrm{SO}_{4} \cdot 10 \mathrm{H}_{2} \mathrm{O}$ and $\mathrm{MgSO}_{4} \cdot 11 \mathrm{H}_{2} \mathrm{O}$ are abundant in Holocene ice, while $\mathrm{CaSO}_{4} \cdot 2 \mathrm{H}_{2} \mathrm{O}$ and other salts are abundant in LGM ice. Further, the number of $\mathrm{CaSO}_{4} \cdot 2 \mathrm{H}_{2} \mathrm{O}$ particles is strongly correlated with the concentration of $\mathrm{Ca}^{2+}$ during Termination I. Taken together, the evidence strongly suggests that most of the $\mathrm{Ca}^{2+}$ exists as $\mathrm{CaSO}_{4} \cdot 2 \mathrm{H}_{2} \mathrm{O}$. The different compositions of microparticles from the Holocene and LGM can be explained by ion balance arguments.
\end{abstract}

\section{INTRODUCTION}

The Earth's climate history over the past several hundred thousand years has been preserved in Antarctic ice cores. Impurities in the ice provide significant information on several aspects of past climates. For instance, it is possible to reconstruct the sea-ice extent from sodium ion $\left(\mathrm{Na}^{+}\right)$ concentrations (lizuka and others, 2008a; Wolff and others, 2010), marine biological activity from sulfate $\left(\mathrm{SO}_{4}{ }^{2-}\right)$ (e.g. Wolff and others, 2010), volcanism from $\mathrm{SO}_{4}{ }^{2-}$ spikes (Castellano and others, 2004) and hydrological cycles from insoluble dust (Lambert and others, 2008).

Several of these impurities are transported to the ice sheet as aerosols. Penner and others (2001) have suggested that in the preindustrial atmosphere the radiative forcing of sulfate aerosols produces negative feedback that cools the Earth in two ways: directly through radiation and indirectly because the sulfates serve as cloud condensation nuclei (e.g. Charlson and others, 1987). The feedback processes related to aerosols in the atmosphere may even have triggered transitions between glacial and interglacial periods. Previous studies have used the insoluble dust concentration in ice cores to infer the radiative forcing of aerosols between the Last Glacial Maximum (LGM) and the Holocene (Claquin and others, 2003; Chylek and Lohmann, 2008). However, the role of water-soluble aerosols in past climates is not yet clear due to the difficulty in reconstructing the chemical forms of impurities from ion concentrations measured in the melted samples. To reconstruct the history of atmospheric aerosols and infer their effects on past climates from impurities in ice cores we must first be able to confirm the chemical form of these impurities and accurately model their behavior during deposition and preservation.

In a shallow section of the Dome Fuji ice core, our recent studies using micro-Raman spectroscopy proved that most $\mathrm{SO}_{4}{ }^{2-}$ was in the form of solid salt particles (Ohno and others, 2005, 2006; Sakurai and others, 2010a,b). The chemical form of the salts altered in each climatic period. In the Dome Fuji ice core, the Holocene and interglacial periods included mainly $\mathrm{Na}_{2} \mathrm{SO}_{4} \cdot 10 \mathrm{H}_{2} \mathrm{O}$ (mirabilite) and $\mathrm{MgSO}_{4} \cdot 11 \mathrm{H}_{2} \mathrm{O}$ (meridianiite) (Genceli and others, 2009). (For more than a century, researchers had assumed that the number of hydrates associated with $\mathrm{MgSO}_{4}$ was 12 . However, Peterson and others (2007) and Genceli and others (2007) found $\mathrm{MgSO}_{4} \cdot 11 \mathrm{H}_{2} \mathrm{O}$. This study adopts their result.) In glacial periods, especially the LGM, the most common sulfate salt was $\mathrm{CaSO}_{4} \cdot 2 \mathrm{H}_{2} \mathrm{O}$ (gypsum) (Ohno and others, 2005). This difference can be inferred rigorously from ion balance arguments (lizuka and others, 2008b), which have been summarized by lizuka and others (2009). However, few studies have attempted to clarify the relationship between water-soluble aerosols and climate change based on ion concentration data and ion balance. To clarify this point, this paper focuses on the climate transition during Termination I (from LGM to Holocene) as recorded in the Dome Fuji ice core.

We counted the number of microparticles in the ice using an optical microscope in a cold clean room $\left(-15^{\circ} \mathrm{C}\right)$. We determined the chemical form of the microparticles by micro-Raman spectroscopy and measured the total ion content by ion chromatography.

\section{METHOD}

The Dome Fuji station is located at the highest point on the east Dronning Maud Land plateau in central Antarctica (3810 m a.s.I.) The first Dome Fuji ice core (2503.52 m deep) was drilled at this station in 1995/96 (Dome-F Deep Coring Group, 1998). The core was transported to the Institute of Low Temperature Science in Hokkaido, Japan, where it is stored in a cold room at $-50^{\circ} \mathrm{C}$. We used eight samples (one LGM, six Termination I and one Holocene), which are dated at $10.3 \mathrm{ka}$ BP $(340.38-340.39 \mathrm{~m}), 11.8 \mathrm{ka}$ BP (382.86$382.87 \mathrm{~m}), 13.2 \mathrm{ka}$ BP $(414.36-414.37 \mathrm{~m}), 15.6 \mathrm{ka}$ ВP (463.85-463.86 $\mathrm{m}$ and 464.33-464.34 m), $18.5 \mathrm{ka} \mathrm{BP}$ 


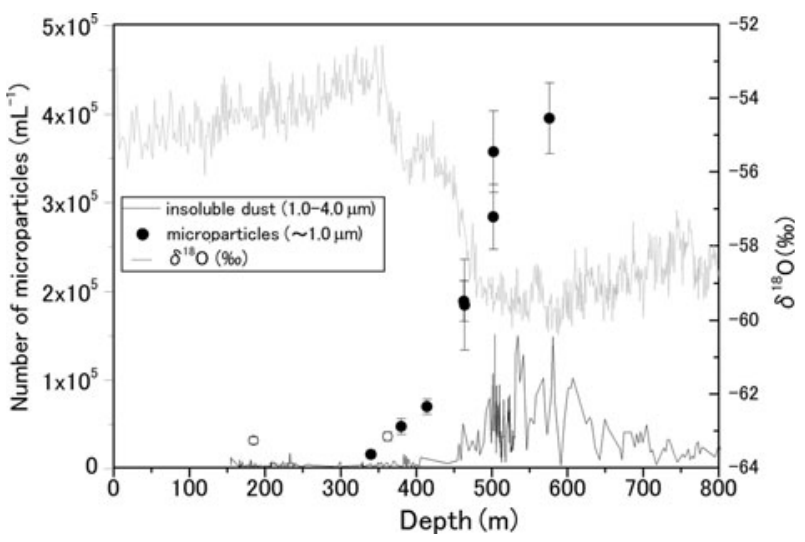

Fig. 1. The number of microparticles (points) and dust concentrations (solid line) shown as a function of depth during Termination I. The data are plotted against insoluble dust and $\delta^{18} \mathrm{O}$ concentrations (lines) measured by Fujii and others (2003) and Watanabe and others (2003), respectively. The solid circles indicate measurements made in this study, and the open circles indicate measurements made in previous research (Ohno and others, 2005). To assess the level of human error we repeated the measurement of number concentration made in Ohno and others (2005) and obtained number concentrations of $4.3 \times 10^{5}$ and $3.9 \times 10^{5} \mathrm{~mL}^{-1}$, respectively.

(502.35-502.36 $\mathrm{m}$ and 502.79-502.80 $\mathrm{m})$ and $24.5 \mathrm{ka} \mathrm{BP}$ (576.50-576.51 m) (Watanabe and others, 2003). Each core sample was cut with a bandsaw into three sections to carry out three independent measurements: the number density of microparticles, the chemical forms of the microparticles and the ion concentrations in melted ice. The sections used to measure number density and chemical forms were cut into dimensions of $50 \mathrm{~mm} \times 10 \mathrm{~mm} \times 2 \mathrm{~mm}$. The section used to measure ion concentrations was cut into dimensions of $50 \mathrm{~mm} \times 10 \mathrm{~mm} \times 10 \mathrm{~mm}$.

We observed the microparticles with an optical microscope (Olympus BH2-UMA, objective lens Olympus ULWD Neo SPlan 50, numerical aperture (NA) 0.55, magnification $5 \times$ and $50 \times$ ) in a cold clean room at $-15^{\circ} \mathrm{C}$. According to the Becke test, the density contrast between microparticles and the surrounding ice is strong enough to distinguish by optical microscopy. However, we cannot distinguish visually between dust (insoluble) and salt (water-soluble) microparticles, so both types are counted. Microparticles with a diameter more than $1.0 \mu \mathrm{m}$ can be recognized, but diameters less than $2.0 \mu \mathrm{m}$ have a large margin of error. In a given field of view $(0.14 \mathrm{~mm} \times 0.18 \mathrm{~mm} \times$ thickness $(\mathrm{mm}))$, we counted and measured all visible microparticles. We randomly picked 100 views to calculate the average number $\mathrm{mm}^{-3}$ and the standard deviation. The number density was then converted to counts $\mathrm{mL}^{-1}$. All other experimental procedures related to microscopy are as reported in previous works (Ohno and others, 2005; Sakurai and others, 2009).

We used micro-Raman spectroscopy to determine the chemical form of the microparticles using previously developed techniques. A detailed description of the microRaman spectroscopy method is provided by Sakurai and others (2010b).

Ion chromatography (IC) is a common method for measuring the concentrations of ionic species present in an ice sample. We decontaminated the ice samples used for IC by cutting away the surface with a clean ceramic knife on a clean bench in a clean cold room at $-15^{\circ} \mathrm{C}$. The decontaminated ice samples were immediately sealed in a clean polyethylene bag. After melting the ice in its bag outside the cold room, the sample was passed through a filter with $0.45 \mu \mathrm{m}$ diameter pores and analyzed in a Dionex 500 chromatograph. We measured the concentrations of $\mathrm{Na}^{+}, \mathrm{Mg}^{2+}, \mathrm{Ca}^{2+}, \mathrm{Cl}^{-}, \mathrm{NO}_{3}{ }^{-}, \mathrm{SO}_{4}{ }^{2-}$ and others. To test for possible contamination, we measured ultra-pure water using the same method and found no peaks in the chromatograph spectrum. The detection limits for these species are $\sim 0.1 \mu \mathrm{mol} \mathrm{L}-1$. The process of sample preparation has been described in detail by Igarashi and others (1998) and lizuka and others (2006).

\section{RESULTS AND DISCUSSION}

\section{Number of microparticles}

The inclusions observed in the samples were of various shapes. Air hydrates and air bubbles several hundred microns in diameter were clearly visible through a $5 \times$ objective lens. Inclusions a few micrometers in diameter were found when viewing the sample through a $50 \times$ objective lens and number density and diameter of microparticles were measured. The number density of microparticles gradually decreased over time in the transition from the LGM to the Holocene (Fig. 1).

The number density was approximately 25 times higher in the LGM ice than in the Holocene ice. The total number density of microparticles as a function of depth was compared with the number density of dust particles (1.0$4.0 \mu \mathrm{m}$ diameter) identified by laser in Fujii and others (2003). The data of the number density of microparticles measured by microscope are combined with the Raman microscopy results to estimate the number density of particles with each chemical form during Termination I.

\section{Chemical forms of the microparticles}

Termination I ice is known to contain water-soluble microparticles such as $\mathrm{Na}_{2} \mathrm{SO}_{4} \cdot 10 \mathrm{H}_{2} \mathrm{O}$ (mirabilite), $\mathrm{MgSO}_{4} \cdot 11 \mathrm{H}_{2} \mathrm{O}$ (meridianiite), $\mathrm{CaSO}_{4} \cdot 2 \mathrm{H}_{2} \mathrm{O}$ (gypsum) and nitrate with sulfate salt (Fig. $2 \mathrm{~b}-\mathrm{d}$ ). We also found insoluble dust types: feldspar, $\mathrm{SiO}_{2}$ (quartz) and others, the Raman spectra of which are unidentified (Fig. 2e-g). Note that not all the inclusions are single particles; a number of agglomerations were also found (Fig. 2b). We simply classified complex microparticles as one particle of each type regardless of the relative strength of the Raman peak. The number density of particles with each chemical form was estimated from the frequency of chemical forms identified in the subset of microparticles examined using micro-Raman spectroscopy. We classify the particles into five types: $\mathrm{CaSO}_{4} \cdot 2 \mathrm{H}_{2} \mathrm{O}$, $\mathrm{Na}_{2} \mathrm{SO}_{4} \cdot 10 \mathrm{H}_{2} \mathrm{O}$ and/or $\mathrm{MgSO}_{4} \cdot 11 \mathrm{H}_{2} \mathrm{O}, \mathrm{SO}_{4}{ }^{2-}+\mathrm{NO}_{3}{ }^{-}$, $\mathrm{Mg}\left(\mathrm{CH}_{3} \mathrm{SO}_{3}\right)_{2} \cdot 12 \mathrm{H}_{2} \mathrm{O}$ and 'other'. Each frequency is multiplied by the total number concentration of microparticles measured using the optical microscope, as shown in Figure 3. The total number of particles found with each chemical form in this experiment was reported previously (Sakurai and others, 2010a,b). The detection of $\mathrm{Mg}\left(\mathrm{CH}_{3} \mathrm{SO}_{3}\right)_{2} \cdot 12 \mathrm{H}_{2} \mathrm{O}$ has also been reported by Sakurai and others (2010b) and Genceli Guner and others (2010).

The 'other' category includes insoluble dust particles (e.g. feldspar, quartz), particles that could not be identified and particles with no Raman signal other than ice. Note that microparticles with no Raman signal could be Raman 

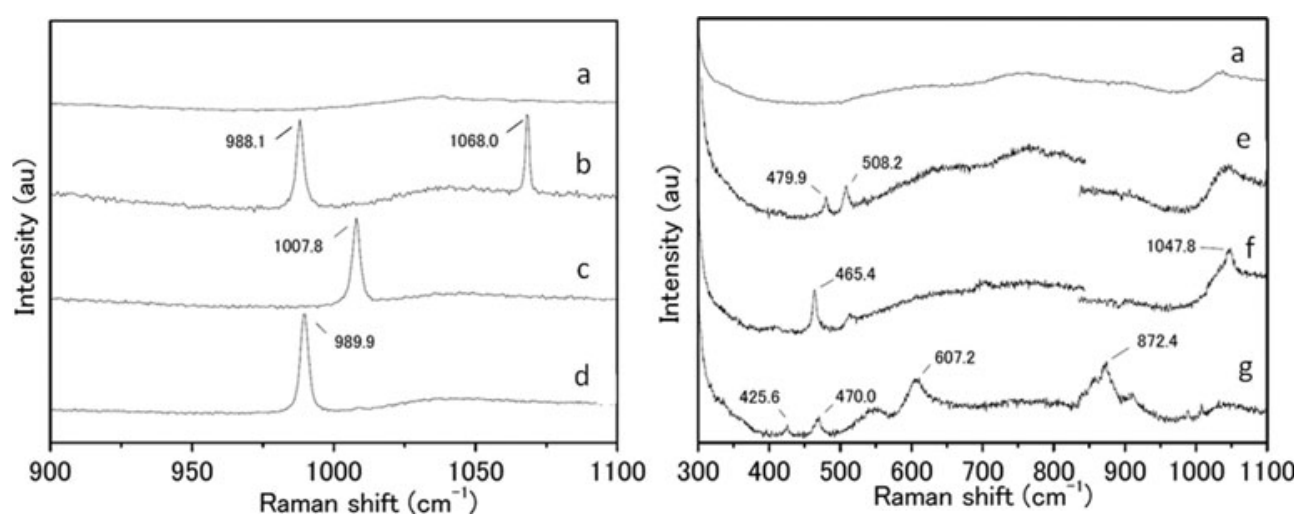

Fig. 2. Typical Raman spectra of microparticles found during Termination I in the Dome Fuji ice core: (a) ice, (b) mixture of sulfate and nitrate salts, (c) $\mathrm{CaSO}_{4} \cdot 2 \mathrm{H}_{2} \mathrm{O}$ (gypsum), (d) $\mathrm{Na}_{2} \mathrm{SO}_{4} \cdot 10 \mathrm{H}_{2} \mathrm{O}$ (mirabilite) or $\mathrm{MgSO}_{4} \cdot 11 \mathrm{H}_{2} \mathrm{O}$ (meridianiite), (e) feldspar, (f) $\mathrm{SiO}_{2}$ (quartz) and (g) an unknown spectrum.

inactive, or the Raman intensity of this mineral may be too low to be identified (Sakurai and others, 2010a). For this reason, our comparison of chemical forms and ion concentrations emphasizes the sulfate salts.

We measured the concentrations of major ions by IC. The IC samples were taken from exactly the same depths as those used to observe the microparticles directly (Table 1 ). The concentration of $\mathrm{Ca}^{2+}$ is strongly correlated with the frequency of $\mathrm{CaSO}_{4} \cdot 2 \mathrm{H}_{2} \mathrm{O}$ particles (Fig. 4). This result shows that most of the $\mathrm{Ca}^{2+}$ exists as $\mathrm{CaSO}_{4} \cdot 2 \mathrm{H}_{2} \mathrm{O}$ at every depth of the Termination I ice-core samples. However, there is evidence for bias in the relationship. In this analysis, the intercept of the correlation line implies an excess of $\sim 0.17 \pm 0.05 \mu \mathrm{Eq} \mathrm{L}^{-1}$ of $\mathrm{Ca}^{2+}$ (the error is the residual variance). That is, we expect $0.17 \pm 0.05 \mu \mathrm{Eq} \mathrm{L}^{-1}$ of $\mathrm{Ca}^{2+}$ to exist in other forms such as $\mathrm{Ca}\left(\mathrm{NO}_{3}\right)_{2} \cdot \mathrm{nH}_{2} \mathrm{O}$ and/or $\mathrm{CaCl}_{2} \cdot \mathrm{nH}_{2} \mathrm{O}$ at each depth. This amount is very small compared with the overall concentration of impurities.

To estimate the concentration of $\mathrm{SO}_{4}{ }^{2-}$ in forms other than $\mathrm{CaSO}_{4} \cdot 2 \mathrm{H}_{2} \mathrm{O}$, we use

$$
\text { noCa }{ }^{2+} \mathrm{SO}_{4}{ }^{2-}=\left[\mathrm{SO}_{4}{ }^{2-}-\mathrm{Ca}^{2+}\right] \quad\left(\mu \mathrm{Eq} \mathrm{L}^{-1}\right)
$$

The right-hand side is the difference between two ion concentrations, and the left-hand term signifies the concentration of $\mathrm{SO}_{4}{ }^{2-}$ whose chemical form is something other than $\mathrm{CaSO}_{4} \cdot 2 \mathrm{H}_{2} \mathrm{O}$. This term includes $\mathrm{Na}_{2} \mathrm{SO}_{4} \cdot 10 \mathrm{H}_{2} \mathrm{O}$, $\mathrm{MgSO}_{4} \cdot 11 \mathrm{H}_{2} \mathrm{O}$, sulfuric acid and many other species as well as $\left(\mathrm{NH}_{4}\right)_{2} \mathrm{SO}_{4}$ which was suggested to exist in an Antarctic ice core (Kaufmann and others, 2010), and of course it should be related to the concentration of $\mathrm{NH}_{4}$. However, we could not find $\left(\mathrm{NH}_{4}\right)_{2} \mathrm{SO}_{4}$ in our study.

In contrast, the concentration of $\mathrm{Na}^{+}+\mathrm{Mg}^{2+}\left(\mu \mathrm{EqL}^{-1}\right)$ is not strongly correlated with the frequency of $\mathrm{Na}_{2} \mathrm{SO}_{4} \cdot 10 \mathrm{H}_{2} \mathrm{O}+\mathrm{MgSO}_{4} \cdot 11 \mathrm{H}_{2} \mathrm{O}$, especially in the LGM (Fig. 4). To estimate the chemical forms of the $\mathrm{Na}^{+}$and $\mathrm{Mg}^{2+}$, we estimated the ion balance using

$$
\left[{ }_{\text {noCa }}{ }^{2+} \mathrm{SO}_{4}{ }^{2-}\right]-\left[\mathrm{Na}^{2+}+\mathrm{Mg}^{2+}\right]\left(\mu \mathrm{EqL}^{-1}\right) .
$$

The result is shown in Figure 5. If the value of Equation (2) is $\gtrsim 0$, then $\mathrm{Na}^{+}$and $\mathrm{Mg}^{2+}$ exist as $\mathrm{Na}_{2} \mathrm{SO}_{4} \cdot 10 \mathrm{H}_{2} \mathrm{O}$ and $\mathrm{MgSO}_{4} \cdot 11 \mathrm{H}_{2} \mathrm{O}$, respectively. In fact, we have found abundant $\mathrm{Na}_{2} \mathrm{SO}_{4} \cdot 10 \mathrm{H}_{2} \mathrm{O}$ and $\mathrm{MgSO}_{4} \cdot 11 \mathrm{H}_{2} \mathrm{O}$ in Holocene ice samples (Fig. 3). If the value of Equation (2) is significantly higher than 0 , then the ice should also contain sulfuric acid in liquid form (e.g. Mulvaney and others, 1988; Fukazawa and others, 1998; Barnes and others, 2003). This state, for instance, could be the result of volcanic activity (Castellano and others, 2004). If the value of Equation (2) is $<0$, then $\mathrm{Na}^{+}$and $\mathrm{Mg}^{2+}$ exist in other chemical forms (e.g. chloride, nitrate and methanesulfonate salts). This case is shown in Termination I and the LGM (but not the Holocene). In fact, for instance, we found $\mathrm{Mg}\left(\mathrm{CH}_{3} \mathrm{SO}_{3}\right)_{2} \cdot 12 \mathrm{H}_{2} \mathrm{O}$ (Sakurai and others, 2010b) and the spectrum of nitrate salt with an unknown cation in LGM ice. Previous studies have shown that chloride salt may have existed in the LGM (Röthlisberger and others, 2003; lizuka and others, 2008b). Therefore, Equations (1) and (2) are useful tools for estimating the chemical forms of microparticles based on ion concentrations in the ice.

Based on the above discussion, we can conclude that most of the $\mathrm{Ca}^{2+}$ in the ice core forms $\mathrm{CaSO}_{4} \cdot 2 \mathrm{H}_{2} \mathrm{O}$. The presence of non-sea-salt $\mathrm{Ca}^{2+}$ is considered an indicator of terrestrial input (Wolff and others, 2010). Previous studies suggest that the formation of $\mathrm{CaSO}_{4} \cdot 2 \mathrm{H}_{2} \mathrm{O}$ by neutralized reaction of terrestrial dust (i.e. $\mathrm{Ca}^{2+}$ ) with non-sea-salt sulfuric acid is dominant especially in the glacial maxima (Röthlisberger and others, 2003; Ohno and others, 2006; lizuka and others, 2008b). On the other hand, gypsum $\left(\mathrm{CaSO}_{4} \cdot 2 \mathrm{H}_{2} \mathrm{O}\right)$ was found in the rock wall of a dry valley in the Sør Rondane Mountains, Antarctica (Matsuoka, 1995; Matsuoka and others, 1996). We analyzed a sample from

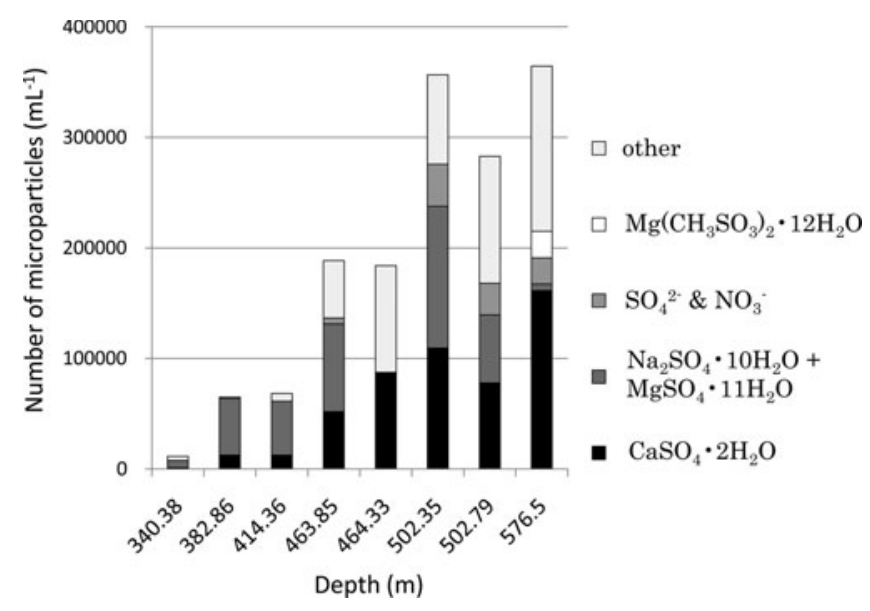

Fig. 3. Total number density of microparticles found at each depth of Termination I, subdivided by the type of salt over Termination I. 
Table 1. Microparticle number and ion concentration during Termination I, Dome Fuji ice core

\begin{tabular}{|c|c|c|c|c|c|c|c|c|c|c|c|c|}
\hline \multirow[t]{2}{*}{ Period } & Depth & Age & $\begin{array}{c}\text { Particle number } \\
\text { concentration }\end{array}$ & $\mathrm{Na}^{+}$ & $\mathrm{NH}_{4}{ }^{+}$ & $\mathrm{K}^{+}$ & $\mathrm{Mg}^{2+}$ & $\mathrm{Ca}^{2+}$ & $\mathrm{CH}_{3} \mathrm{SO}_{3}^{-}$ & $\mathrm{Cl}^{-}$ & $\mathrm{NO}_{3}{ }^{-}$ & $\mathrm{SO}_{4}{ }^{2-}$ \\
\hline & $\mathrm{m}$ & ka BP & $\mathrm{mL}^{-1}$ & $\mu \mathrm{mol} \mathrm{L}{ }^{-1}$ & $\mu \mathrm{mol} \mathrm{L}^{-1}$ & $\mu \mathrm{mol} \mathrm{L}{ }^{-1}$ & $\mu \mathrm{mol} \mathrm{L}^{-1}$ & $\mu \mathrm{mol} \mathrm{L}^{-1}$ & $\mu \mathrm{mol} \mathrm{L}-1$ & $\mu \mathrm{mol} \mathrm{L}-1$ & $\mu \mathrm{mol} \mathrm{L}^{-1}$ & $\mu \mathrm{mol} \mathrm{L}-1$ \\
\hline Holocene & 340.38 & 10.3 & $0.16 \times 10^{5}$ & 1.35 & 0.35 & 0.35 & 0.13 & 0.30 & - & 1.17 & 0.54 & 1.08 \\
\hline Termination I & 382.86 & 11.8 & $0.66 \times 10^{5}$ & 2.03 & 0.14 & 0.21 & 0.23 & 0.30 & 0.20 & 1.11 & 0.23 & 1.08 \\
\hline Termination I & 414.36 & 13.2 & $0.69 \times 10^{5}$ & 2.55 & 0.35 & 0.17 & 0.30 & 0.28 & 0.23 & 1.15 & 0.36 & 1.22 \\
\hline Termination I & 463.85 & 15.6 & $1.90 \times 10^{5}$ & 3.35 & 0.19 & 0.23 & 0.58 & 1.32 & 0.31 & 4.07 & 1.81 & 1.16 \\
\hline Termination I & 464.33 & 15.6 & $1.84 \times 10^{5}$ & 3.29 & 0.22 & 0.28 & 0.53 & 0.79 & 0.27 & 3.47 & 0.92 & 1.43 \\
\hline Termination I & 502.35 & 18.5 & $3.57 \times 10^{5}$ & 4.54 & 0.28 & 0.35 & 0.80 & 1.62 & 0.23 & 5.00 & 1.51 & 1.98 \\
\hline Termination I & 502.79 & 18.5 & $2.83 \times 10^{5}$ & 4.50 & 0.36 & 0.44 & 0.77 & 1.44 & 0.18 & 5.55 & 1.75 & 2.01 \\
\hline LGM & 576.50 & 24.5 & $3.94 \times 10^{5}$ & 5.29 & - & 0.25 & 0.89 & 1.55 & 0.19 & 5.36 & 1.62 & 2.48 \\
\hline
\end{tabular}

this rock wall, which showed exactly the same Raman spectra as the $\mathrm{CaSO}_{4} \cdot 2 \mathrm{H}_{2} \mathrm{O}$ microparticles in our ice-core samples (Fig. 6). This result may suggest that some terrestrial $\mathrm{CaSO}_{4} \cdot 2 \mathrm{H}_{2} \mathrm{O}$ has come to the ice sheet not just from South America, but also from the Dry Valleys of Antarctica, as has been suggested from ${ }^{87} \mathrm{Sr} /{ }^{86} \mathrm{Sr}$ and ${ }^{143} \mathrm{Nd} /{ }^{144} \mathrm{Nd}$ isotopic tracers (Delmonte and others, 2004). A numerical model also suggested that the air in Antarctica may be transported from the coast to the interior (Suzuki and others, 2008). In addition, Sala and others (2008) found $\mathrm{CaCO}_{3}$ with hydrate from Talos Dome, northern Victoria Land, Antarctica, and they suggest that the $\mathrm{CaCO}_{3}$ with hydrate is derived from the sea-ice surface. It is still unclear what percentage of $\mathrm{CaSO}_{4} \cdot 2 \mathrm{H}_{2} \mathrm{O}$ in ice is formed in the air, the terrestrial
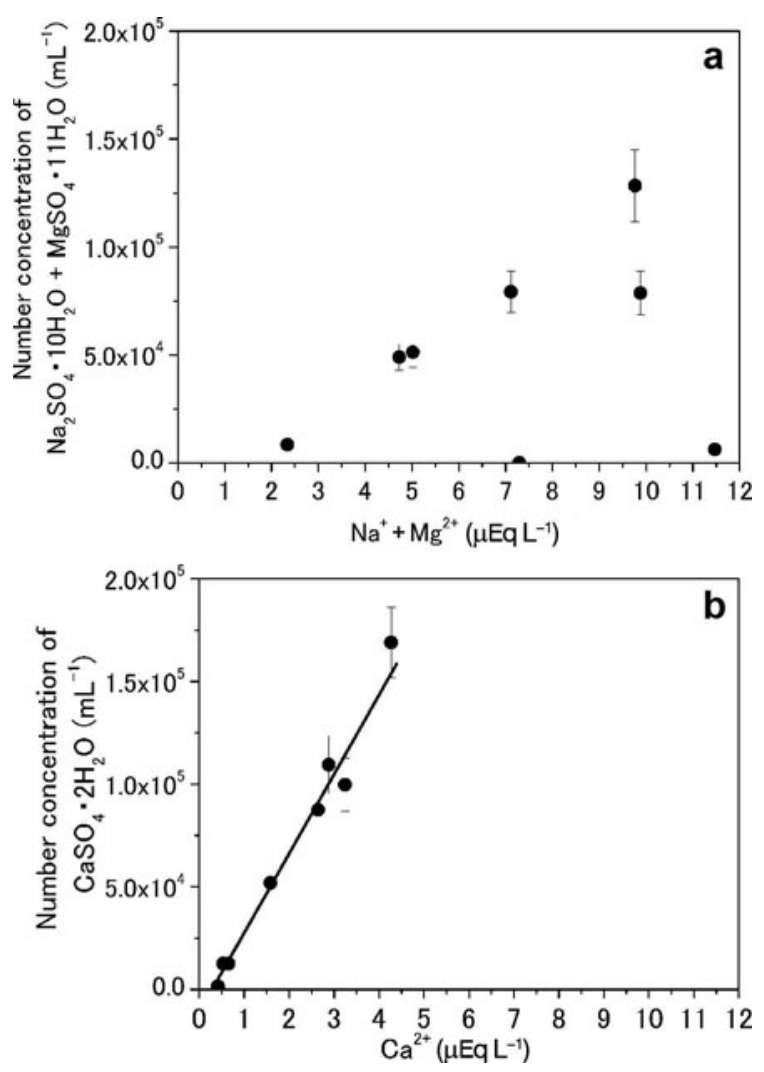

Fig. 4. Two observed relationships between ion concentrations and the number density of sulfate microparticles. The correlation coefficient of (a) $\mathrm{Na}_{2} \mathrm{SO}_{4} \cdot 10 \mathrm{H}_{2} \mathrm{O}+\mathrm{MgSO}_{4} \cdot 11 \mathrm{H}_{2} \mathrm{O}$ and $\mathrm{Na}^{+}+\mathrm{Mg}^{2+}$ is 0.08 , while that of (b) $\mathrm{CaSO}_{4} \cdot 2 \mathrm{H}_{2} \mathrm{O}$ and $\mathrm{Ca}^{2+}$ is $0.86(p=0.01)$. region or derived from terrestrial erosion. A previous study has shown in the case of Termination I that the concentration of non-sea-salt $\mathrm{Ca}^{2+}$ flux decreases as the temperature $(\delta \mathrm{D})$ of the ice increases and the sea-salt $\mathrm{Na}^{+}$flux (sea-ice proxy) did not correspond well with $\mathrm{Ca}^{2+}$ flux (Röthlisberger and others, 2008). Therefore, the non-sea-salt $\mathrm{Ca}^{2+}$ which we conclude is in the chemical form of $\mathrm{CaSO}_{4} \cdot 2 \mathrm{H}_{2} \mathrm{O}$ could be transported from the Dry Valleys of Antarctica.

\section{CONCLUSIONS}

We determined the chemical forms of individual watersoluble microparticles through micro-Raman spectroscopy and compared the number of sulfate particles and ion concentrations during Termination I, in the Dome Fuji ice core. The evidence from this study strongly suggests that most of the $\mathrm{Ca}^{2+}$ exists as $\mathrm{CaSO}_{4} \cdot 2 \mathrm{H}_{2} \mathrm{O}$. The sulfate compositions of microparticles from the Holocene and LGM can be explained by ion balance arguments. We also determined that the $\mathrm{CaSO}_{4} \cdot 2 \mathrm{H}_{2} \mathrm{O}$ is found in the Dry Valleys of Antarctica. It is still unclear what percentage of $\mathrm{CaSO}_{4} \cdot 2 \mathrm{H}_{2} \mathrm{O}$ in ice is formed in the air or by terrestrial erosion, but we suggest that the $\mathrm{CaSO}_{4} \cdot 2 \mathrm{H}_{2} \mathrm{O}$ may be of terrestrial origin, not just from South America but also from the Dry Valleys of Antarctica. Further studies of the chemical form of microparticles in ice cores are needed to clarify the origins and physical chemistry of atmospheric aerosols in the past including $\mathrm{CaSO}_{4} \cdot 2 \mathrm{H}_{2} \mathrm{O}$.

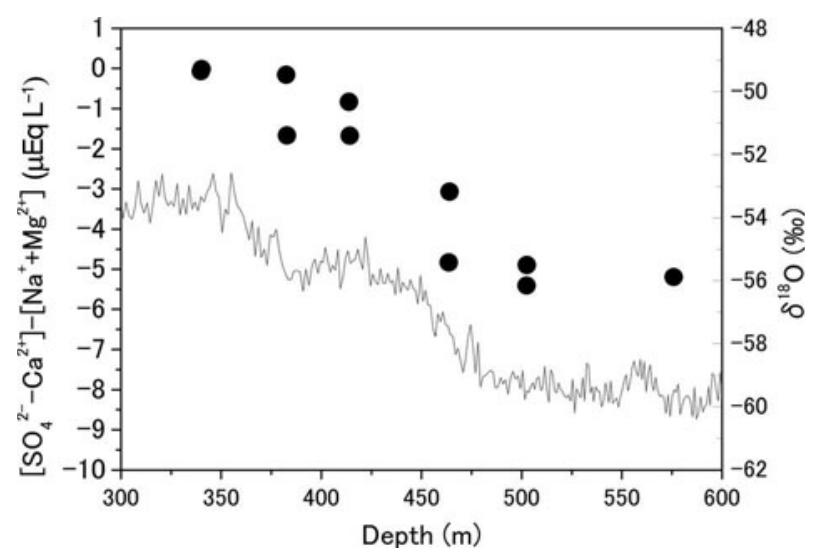

Fig. 5. Ion balance calculated from Equation (2) during Termination I. The $\delta^{18} \mathrm{O}$ data are from Watanabe and others (2003). 


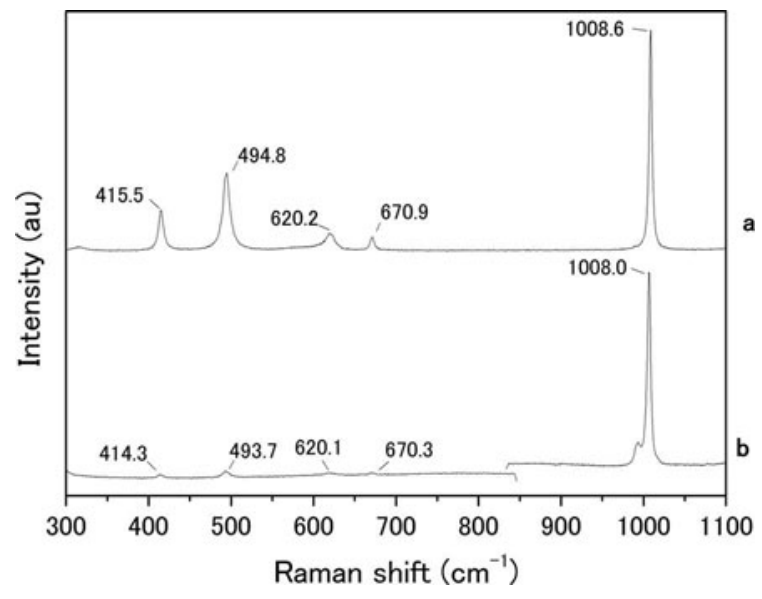

Fig. 6. (a) Raman spectrum of the rock wall of the Sør Rondane Mountains, and (b) reference Raman spectrum of $\mathrm{CaSO}_{4} \cdot 2 \mathrm{H}_{2} \mathrm{O}$.

\section{ACKNOWLEDGEMENTS}

We thank the Dome Fuji drilling team, and A. Hori and A. Miyamoto for valuable discussions. This study was supported by Grants-in-Aid for Creative Scientific Research (grant Nos. 14GS0202 and 21710002), by the Grant for Joint Research Program of the Institute of Low Temperature Science, Hokkaido University, by the Hokkaido University Global Center of Excellence (COE) program (Establishment of a Center for Integrated Field Environmental Science), and by a Special Education Study Expense account (cooperation between universities) provided by Japan's Ministry of Education, Culture, Sports, Science and Technology (MEXT) and the Japan Society for the Promotion of Science (JSPS). We sincerely thank the scientific editor, D. Peel. for valuable comments and suggestions, and two anonymous reviewers who improved the clarity of the manuscript.

\section{REFERENCES}

Barnes, P.R.F., E.W. Wolff, H.M. Mader, R. Udisti, E. Castellano and R. Röthlisberger. 2003. Evolution of chemical peak shapes in the Dome C, Antarctica, ice core. J. Geophys. Res., 108(D3), 4126. (10.1029/2002JD002538.)

Castellano, E. and 7 others. 2004. Volcanic eruption frequency over the last $45 \mathrm{ky}$ as recorded in Epica-Dome C ice core (East Antarctica) and its relationship with climatic changes. Global Planet. Change, 42(1-4), 195-205.

Charlson, R.J., J.E. Lovelock, M.O. Andreae and S.G. Warren. 1987. Oceanic phytoplankton, atmospheric sulphur, cloud albedo and climate. Nature, 326(6114), 655-661.

Chylek, P. and U. Lohmann. 2008. Aerosol radiative forcing and climate sensitivity deduced from the Last Glacial Maximum to Holocene transition. Geophys. Res. Lett., 35(4), L04804. (10.1029/2007GL032759.)

Claquin, T. and 11 others. 2003. Radiative forcing of climate by iceage atmospheric dust. Climate Dyn., 20(2-3), 193-202.

Delmonte, B. and 6 others. 2004. Comparing the EPICA and Vostok dust records during the last 220,000 years: stratigraphical correlation and provenance in glacial periods. Earth-Sci. Rev., 66(1-2), 63-87.

Dome-F Deep Coring Group. 1998. Deep ice-core drilling at Dome Fuji and glaciological studies in east Dronning Maud Land, Antarctica. Ann. Glaciol., 27, 333-337.

Fujii, Y., M. Kohno, S. Matoba, H. Motoyama and O. Watanabe. 2003. A 320 k-year record of microparticles in the Dome Fujii, Antarctic ice core measured by laser scattering method. Mem. Natl Inst. Polar Res., Special Issue 57, 46-62.
Fukazawa, H., K. Sugiyama, S. Mae, H. Narita and T. Hondoh. 1998. Acid ions at triple junction of Antarctic ice observed by Raman scattering. Geophys. Res. Lett., 25(15), 2845-2848.

Genceli, F.E., A.L. Lutz, A.L. Spek and G.-J. Witkamp. 2007. Crystallization and characterization of a new magnesium sulphate $\mathrm{MgSO}_{4} \cdot 11 \mathrm{H}_{2} \mathrm{O}$. Cryst. Growth Des., 7(12), 2460-2466.

Genceli, F.E. and 6 others. 2009. Meridianiite detected in ice. J. Glaciol., 55(189), 117-122.

Genceli Guner, F.E., M. Lutz, T. Sakurai, A.L. Spek and T. Hondoh. 2010. Crystallization and characterization of magnesium methanesulfonate hydrate $\mathrm{Mg}\left(\mathrm{CH}_{3} \mathrm{SO}_{3}\right)_{2} \cdot 12 \mathrm{H}_{2} \mathrm{O}$. Cryst. Growth Des., 10(10), 4327-4333.

Igarashi, M., N. Kanamori and O. Watanabe. 1998. Analytical method for small amount of polar snow and ice samples by ion chromatography. Antarct. Rec., 42(1), 64-80. [In Japanese with English summary.]

lizuka, Y., T. Hondoh and Y. Fujii. 2006. $\mathrm{Na}_{2} \mathrm{SO}_{4}$ and $\mathrm{MgSO}_{4}$ salts during the Holocene period derived by high-resolution depth analysis of a Dome Fuji ice core. J. Glaciol., 52(176), 58-64.

lizuka, Y., T. Hondoh and Y. Fujii. 2008a. Antarctic sea ice extent during the Holocene reconstructed from inland ice core evidence. J. Geophys. Res., 113(D15), D15114. (10.1029/ 2007JD009326.)

lizuka, Y. and 6 others. 2008b. A relationship between ion balance and the chemical compounds of salt inclusions found in the Greenland Ice Core Project and Dome Fuji ice cores. J. Geophys. Res., 113(D7), D07303. (10.1029/2007JD009018.)

lizuka, Y., H. Ohno, T. Sakurai, S. Horikawa and T. Hondoh. 2009. Chemical compounds of water-soluble impurities in Dome Fuji Ice Core. In Hondoh, T., ed. Physics of ice core records II. Sapporo, Hokkaido University Press, 273-285. (Supplement Issue of Low Temperature Science 68.)

Kaufmann, P. and 11 others. 2010. Ammonium and non-sea salt sulfate in the EPICA ice cores as indicator of biological activity in the Southern Ocean. Quat. Sci. Rev., 29(1-2), 313-323.

Lambert, F. and 9 others. 2008. Dust-climate couplings over the past 800,000 years from the EPICA Dome C ice core. Nature, 452(7187), 616-619.

Matsuoka, N. 1995. Rock weathering processes and landform development in the Sør Rondane Mountains, Antarctica. Geomorphology, 12(4), 323-339.

Matsuoka, N., K. Moriwaki and K. Hirakawa. 1996. Field experiments on physical weathering and wind erosion in an Antarctic cold desert. Earth Surf. Process. Landf., 21(8), 687-699.

Mulvaney, R., E.W. Wolff and K. Oates. 1988. Sulphuric acid at grain boundaries in Antarctic ice. Nature, 331(6153), 247-249.

Ohno, H., A. Igarashi and T. Hondoh. 2005. Salt inclusions in polar ice core, location and chemical form of water-soluble impurities. Earth Planet. Sci. Lett., 232(1-2), 171-178.

Ohno, H., M. Igarashi and T. Hondoh. 2006. Characteristics of salt inclusions in polar ice from Dome Fuji, East Antarctica. Geophys. Res. Lett., 33(8), L08501. (10.1029/2006GL025774.)

Penner, J.E. and 10 others. 2001. Aerosols, their direct and indirect effects. In Houghton, J.T. and 7 others, eds. Climate Change 2001: the scientific basis. Contribution of Working Group I to the Third Assessment Report of the Intergovernmental Panel on Climate Change. Cambridge, etc., Cambridge University Press, 289-348.

Peterson, R.C., W. Nelson, B. Madu and H.F. Shurvell. 2007. Meridianiite: a new mineral species observed on Earth and predicted to exist on Mars. Am. Mineral., 92(10), 1756-1759.

Röthlisberger, R. and 8 others. 2003. Limited dechlorination of seasalt aerosols during the last glacial period: evidence from the (EPICA) Dome C ice core. J. Geophys. Res., 108(D16), 4256. (10.1029/2003JD003604.)

Röthlisberger, R. and 10 others. 2008. The Southern Hemisphere at glacial terminations: insights from the Dome $\mathrm{C}$ ice core. Climate Past, 4(4), 345-356. 
Sakurai, T. and 6 others. 2009. Direct observation of salts as microinclusions in the Greenland GRIP ice core. J. Glaciol., 55(193), 777-783.

Sakurai, T., H. Ohno, S. Horikawa, Y. lizuka, T. Uchida and T. Hondoh. 2010a. A technique for measuring microparticles in polar ice using micro-Raman spectroscopy. Int. J. Spectrosc., 2010, 384956. (10.1155/2010/384956.)

Sakurai, T. and 6 others. 2010b. Magnesium methanesulfonate salt found in the Dome Fuji (Antarctica) ice core. J. Glaciol., 56(199), 837-842.

Sala, M. and 10 others. 2008. Evidence of calcium carbonates in coastal (Talos Dome and Ross Sea area) East Antarctica snow and firn: environmental and climatic implications. Earth Planet. Sci. Lett., 271(1-4), 43-52.

Suzuki, K., T. Yamanouchi and H. Motoyama. 2008. Moisture transport to Syowa and Dome Fuji stations in Antarctica. J. Geophys. Res., 113(D24), D24114. (10.1029/2008JD009794.)

Watanabe, O., J. Jouzel, S. Johnsen, F. Parrenin, H. Shoji and N. Yoshida. 2003. Homogeneous climate variability across East Antarctica over the past three glacial cycles. Nature, 422(6931), 509-512.

Wolff, E.W. and 29 others. 2010. Changes in environment over the last 800,000 years from chemical analysis of the EPICA Dome C ice core. Quat. Sci. Rev., 29(1-2), 285-295.

MS received 12 January 2011 and accepted in revised form 21 August 2011 